Anna Gadomska-Radel

Uniwersytet w Biatymstoku

\title{
PRZESŁUCHANIE DZIECKA W POLSKIM PROCESIE KARNYM W ŚWIETLE STANDARDÓW EUROPEJSKICH
}

Wzrost świadomości występowania problemu krzywdzenia dzieci wiąże się $\mathrm{z}$ coraz większą uwagą poświęcaną na całym świecie ochronie praw dziecka w toku postępowania karnego, wzmocnienia pozycji dziecka - ofiary przestępstwa w procesie karnym, zabezpieczenia jego uzasadnionych interesów i zapobiegania wtórnej wiktymizacji ze strony organów ścigania i wymiaru sprawiedliwości. Świadczą o tym międzynarodowe wymagania i zalecenia, jakim powinny sprostać ustawodawstwa poszczególnych państw. Ponadto na tym tle w ostatnich latach jest prowadzona szeroko zakrojona polityka państw członkowskich Unii Europejskiej, w tym Polski, zmierzająca do zapewnienia kompleksowej ochrony dziecka w trakcie czynności przesłuchania w postępowaniu karnym.

Standardy europejskie w zakresie przesłuchania dziecka w postępowaniu karnym oraz zabezpieczenia jego uzasadnionych interesów znajdują odzwierciedlenie w polskim procesie karnym. Niewątpliwie wyrazem troski zapewnienia ochrony dziecku pokrzywdzonemu przestępstwem jest art. 185a k.p.k. wprowadzony do kodeksu postępowania karnego nowelizacją z dnia 10 stycznia 2003 r., w brzmieniu ustalonym przez ustawę z dnia 3 czerwca 2005 r. oraz ustawę z dnia 13 czerwca 2013 r. $^{1}$ Ratio legis art. 185a k.p.k. ma na celu zapewnienie pokrzywdzonemu dziecku jak najkorzystniejszych warunków do swobodnego złożenia zeznań oraz zminimalizowanie stresu wywołanego przesłuchaniem i odtwarzaniem przebiegu przestępstwa, a tym samym powracaniem do związanych z tym przeżyć, które mogą powodować zaburzenia funkcjonowania organizmu, w tym pamięci. Należy zauważyć, że przeciwdziałanie wtórnej wiktymizacji pokrzywdzonych przestępstwem,

$1 \quad$ Art. 185 a dodany przez art. 1 pkt 62 ustawy z dnia 10 stycznia 2003 r. o zmianie ustawy - Kodeks postępowania karnego, ustawy - Przepisy wprowadzające Kodeks postępowania karnego, ustawy o świadku koronnym oraz ustawy o ochronie informacji niejawnych (Dz.U. z 2003 r. Nr 17, poz. 155) zmieniającej nin. ustawę z dniem 1 lipca 2003 r. oraz art. 185 a zmieniony przez art. 1 pkt 2 lit. a ustawy z dnia 3 czerwca 2005 r. o zmianie ustawy Kodeks postępowania karnego (Dz.U. z 2003 r. Nr 141, poz. 1181) zmieniającej nin. ustawę z dniem 29 sierpnia 2005 r. oraz art. 185 a zmieniony przez art. 2 ustawy z dnia 13 czerwca 2013 r. o zmianie ustawy - Kodeks karny oraz ustawy - Kodeks postępowania karnego (Dz.U. z 2013 r. Nr 849) zmieniającej nin. ustawę z dniem 27 stycznia 2014 r. 
a więc ponownego narażania pokrzywdzonych na nowe lub pogłębianie szkody wskutek doznanego przestępstwem uszczerbku na zdrowiu, niezależnie od tego, czy spowodowane działaniem sprawcy przestępstw czy organów go ścigających, jest wbudowane w cele procesu karnego. ${ }^{2}$

Szczególna procedura w zakresie przesłuchania dziecka pokrzywdzonego przestępstwem uregulowana w art. 185a k.p.k. została wprowadzona celem dostosowania przepisów prawa karnego procesowego do uchwalonej przez Radę Unii Europejskiej w dniu 15 marca 2001 r. i wiążącej państwa członkowskie Unii Europejskiej Decyzji Ramowej w sprawie pozycji ofiar w postępowaniu karnym. ${ }^{3}$ Jest ona zasadniczym dokumentem dotyczącym ofiar przestępstw, który zawierał uregulowania mające na celu dostarczenie ofiarom przestępstw, w tym ofiarom szczególnie wrażliwym - dzieciom, wysokiego stopnia ochrony ich interesów zarówno w toku postępowania, jak również przed i po celem złagodzenia skutków przestępstwa, niezależnie od państwa, w którym ofiara się znajduje. Założeniem Decyzji Ramowej w odniesieniu do ofiar szczególnie wrażliwych - dzieci było zapewnienie możliwości uniknięcia kontaktu ze sprawcą przestępstwa poprzez wyodrębnienie specjalnych poczekalni dla ofiar oraz ochrony przed skutkami dostarczania dowodów na sali rozpraw poprzez przyznanie im prawa do składania zeznań w sposób umożliwiający osiągnięcie tego celu przez zastosowanie wszelkich środków zgodnych z podstawowymi zasadami prawa. Cel ten nabrał szczególnego wyrazu po wydaniu wyroku Europejskiego Trybunału Sprawiedliwości w sprawie Marii Pupino. ${ }^{4}$ Europejski Trybunał Sprawiedliwości wyraził w nim pogląd, że art. 2, 3 i 8 ust. 4 Decyzji Ramowej należy interpretować w taki sposób, aby sąd krajowy mógł mieć możliwość zezwolenia małym dzieciom, które twierdzą, że padły ofiarą złego traktowania, na składanie zeznań w sposób umożliwiający zagwarantowanie im odpowiedniego poziomu ochrony, na przykład poza rozprawą i przed jej terminem. Zapewni to poszanowanie godności osobistej ofiar w trakcie postępowania oraz traktowanie ofiar szczególnie słabych i wrażliwych w sposób jak najlepiej odpowiadający ich sytuacji.

Ponadto Trybunał Sprawiedliwości wyraził stanowisko, że pomimo, iż decyzja ramowa nie definiuje pojęcia podatności na wiktymizację ofiary w rozumieniu art. 2 ust. 2 oraz art. 8 ust. 4, niewątpliwie w sytuacji, gdy osoba będąca ofiarą danego przestępstwa jest małoletnia, jest co do zasady wystarczająca, aby zakwalifikować ją do szczególnie podatnych na wiktymizację w rozumieniu decyzji ramowej. Tak więc gdy chodzi o małe dzieci, które twierdzą, że były źle traktowane, można je zaliczyć Geneza, istota i rola w przekształcaniu polityki traktowania ofiar przestępstw, Warszawa 2012, s. 80. nym (Dz.U. WE L 82/1). Była ona wiążąca dla Państw Członkowskich Unii Europejskiej do czasu wejścia w życie Dyrektywy 2012/29/UE Parlamentu Europejskiego i Rady ustanawiającej normy minimalne w zakresie praw, wsparcia i ochrony ofiar przestępstw oraz zastępującej decyzję ramową Rady 2001/220/WSiSW (Dz.U. UE L 315/57), data wejścia w życie 15 listopada 2012 r., termin implementacji 16 listopada 2015 r. Wyrok ETS z dnia 16 czerwca 2005 r. Postępowanie karne przeciwko Marii Pupino, C - 105/03, Zbiór Orzecznictwa 2005, s. I - 5285 . 
do tej kategorii ofiar, w szczególności ze względu na ich wiek oraz charakter i skutki przestępstwa popełnionego na ich szkodę. Dlatego też skoro dziecko jest szczególnie wrażliwe i podatne na wiktymizację, to należy mu udzielić szczególnej ochrony w postaci wcześniejszego przeprowadzenia dowodu z zeznań dziecka jako ofiary, szczególnego sposobu składania zeznań, jeśli taki tryb postępowania lepiej odpowiada sytuacji ofiar i jest konieczny celem uniknięcia utraty dowodów, zmniejszenia do minimum liczby przesłuchań dzieci oraz zapobieżenia negatywnym skutkom składania zeznań na rozprawie. Ponadto w niniejszym orzeczeniu Trybunał uznał, że dzieci skrzywdzone przestępstwem innym niż popełnionym na tle seksualnym mają również prawo do szczególnego trybu przesłuchania i zagwarantowania im odpowiedniego sposobu ochrony.

Orzeczenie wydane w sprawie Marii Pupino nie pozostawia wątpliwości, że interpretacja przepisów krajowych musi zmierzać w kierunku maksymalnego poszanowania praw dziecka. Jednocześnie zawarte $\mathrm{w}$ nim tezy mają ogromne znaczenie dla praktyki orzeczniczej w państwach członkowskich w zakresie ochrony dziecka ofiary lub świadka przestępstwa.

Odnosząc się do treści art. 185a k.p.k. wskazania wymaga, że regulacja ta początkowo miała na celu ochronę dzieci pokrzywdzonych przestępstwem określonym w rozdziale XXV kodeksu karnego, tj. przeciwko wolności seksualnej i obyczajności oraz rozdziale XXVI kodeksu karnego, tj. przeciwko rodzinie i opiece, które w chwili przesłuchania nie ukończyły 15 lat. Ustawodawca polski uznał także konieczność objęcia ochroną małoletniego świadka przestępstwa, który w chwili przesłuchania nie ukończył 15 lat w sprawach o przestępstwa popełnione z użyciem przemocy lub groźby bezprawnej lub o przestępstwa określone w rozdziale XXV kodeksu karnego, czego wyrazem jest treść art. 185b k.p.k. ${ }^{5}$ Wynika z tego, że tylko ściśle ograniczony krąg dzieci został objęty specjalną procedurą stosowaną $\mathrm{w}$ trakcie czynności przesłuchania. W konsekwencji dzieci pokrzywdzone innym rodzajem przestępstw niż wskazane w art. 185a k.p.k. nie były chronione przed negatywnymi przeżyciami związanymi z koniecznością opowiedzenia przebiegu zdarzenia będącego przedmiotem postępowania. Dlatego też w celu zapewnienia dziecku szerszej ochrony przed wtórną wiktymizacją i utrwalaniem się w jego psychice traumatycznych przeżyć wywołanych popełnionym czynem zabronionym, nowelizacją ustawy - Kodeks postępowania karnego z 2013 r. ${ }^{6}$ rozszerzono katalog przestępstw, w którym ma zastosowanie szczególny tryb przesłuchania dziecka określony w art. 185a i art. 185b k.p.k. Dokonanie zmiany w tym zakresie stanowi jednocześnie wyraz uwzględnienia w polskim procesie karnym standardów europejskich odnoszących

Art. 185 b dodany przez art. 1 pkt 3 ustawy z dnia 3 czerwca 2005 r. o zmianie ustawy - Kodeks postępowania karnego (Dz.U. z 2005 r. Nr 141, poz. 1181) zmieniającej nin. ustawę z dniem 29 sierpnia 2005 r.

$6 \quad$ Art. 185 a i art. 185 b zmienione przez art. 2 pkt 3 ustawy z dnia 13 czerwca 2013 r. o zmianie ustawy - Kodeks karny oraz ustawy - Kodeks postępowania karnego (Dz.U. z 2013 r. Nr 849) zmieniającej nin. ustawę z dniem 27 stycznia 2014 r. 
się do procedury przesłuchania małoletniego wynikających z obowiązujących dyrektyw unijnych ${ }^{7}$, zwanych dalej Dyrektywami.

W odniesieniu do małoletniego pokrzywdzonego katalog czynów zabronionych po nowelizacji objął także przestępstwa popełnione z użyciem przemocy lub groźby bezprawnej lub przeciwko wolności (określone w rozdziale XXIII kodeksu karnego). Wprowadzenie zmian w art. 185a k.p.k. jest przede wszystkim wynikiem wdrożenia do polskiego systemu prawa karnego art. 15 ust. 3-5 Dyrektywy Parlamentu Europejskiego i Rady 2011/36/UE z dnia 5 kwietnia 2011 r. w sprawie zapobiegania handlowi ludźmi i zwalczania tego procederu oraz ochrony ofiar, poprzez dodanie art. 189a kodeksu karnego ${ }^{8}$ - odnoszącego się do handlu ludźmi. Natomiast w stosunku do małoletnich świadków przestępstwa katalog przestępstw oprócz dotychczasowych przestępstw obejmuje także przestępstwa przeciwko rodzinie i opiece (określone w rozdziale XXVI kodeksu karnego). Zmiana ta podyktowana jest faktem, iż w praktyce bardzo często występują sytuacje, że dzieci są świadkami przestępstw popełnianych na szkodę ich najbliższych, co powoduje trudność związaną z koniecznością opowiadania przebiegu zdarzenia przestępczego. Dlatego też uzasadnione jest zapewnienie im stosowania specjalnego trybu przesłuchania.

W treści art. 2 ust. 6 Dyrektywy Parlamentu Europejskiego i Rady 2011/36/UE z dnia 5 kwietnia $2011 \mathrm{r}$. w sprawie zapobiegania handlowi ludźmi i zwalczania tego procederu oraz ochrony ofiar oraz art. art. 2 ust. 1 lit. c Dyrektywy Parlamentu Europejskiego i Rady z dnia 25 października 2012 r. ustanawiającej normy minimalne w zakresie praw, wsparcia i ochrony ofiar przestępstw pojawiło się także pojęcie dziecka, którym jest osoba poniżej 18. roku życia i zgodnie z dalszymi postanowieniami powyżej wskazanych Dyrektyw dziecko w takim rozumieniu ma szczególne potrzeby w zakresie ochrony w trakcie przesłuchania. W związku z tym w celu dostosowania brzmienia art. 185a k.p.k. do standardów unijnych, rozszerzono nie tylko katalog czynów, do których będzie miał zastosowanie tryb przesłuchania określony w art. 185a k.p.k., ale także objęto ochroną dzieci pokrzywdzone przestępstwem, które w chwili przesłuchania ukończyły 15 lat, gdy zachodzi uzasadniona obawa, że przesłuchanie w innych warunkach mogłoby wywrzeć negatywny wpływ na jego stan psychiczny (art. 185a $\S 4$ k.p.k.). Natomiast w przypadku małoletnich świadków przestępstwa dopuszczalne jest przesłuchanie przy użyciu urządzeń technicz-

7 Dyrektywa 2011/36/UE Parlamentu Europejskiego i Rady z dnia 5 kwietnia 2011 r. w sprawie zapobiegania handlowi ludźmi i zwalczania tego procederu oraz ochrony ofiar, zastępująca decyzję ramową Rady 2002/629/ WSiSW (Dz.U. UE L 101/1 z dnia 15.4.2011 r.), Dyrektywa 2011/92/UE Parlamentu Europejskiego i Rady z dnia 13 grudnia 2011 r. w sprawie zwalczania niegodziwego traktowania w celach seksualnych i wykorzystywania seksualnego dzieci oraz pornografii dziecięcej oraz uchylająca Decyzję Ramową 2004/68/WSiSW (Dz. Urz. UE L 335/1 z dnia 17.12.2011 r.), Dyrektywa 2012/29/UE Parlamentu Europejskiego i Rady z dnia 25 października 2012 r. ustanawiająca normy minimalne w zakresie praw, wsparcia i ochrony ofiar przestępstw oraz zastępująca decyzję ramową 2001/220/WSiSW (Dz.U. UE L 315/57 z dnia 14.11.2012 r.). o Policji, ustawy - Przepisy wprowadzające Kodeks karny oraz ustawy - Kodeks postępowania karnego (Dz.U. z 2010 r. Nr 98, poz. 626). 
nych umożliwiających przeprowadzenie tej czynności na odległość z jednoczesnym bezpośrednim przekazem obrazu i dźwięku (w trybie art. 177 § 1a k.p.k.), gdy zachodzi uzasadniona obawa, że bezpośrednia obecność oskarżonego przy przesłuchaniu mogłaby oddziaływać krępująco na zeznania świadka lub wywierać negatywny wpływ na jego stan psychiczny. Wynika $z$ tego, że w polskim porządku prawnym przesłuchanie dziecka powyżej 15. roku życia z zastosowaniem specjalnej procedury, w odróżnieniu do postanowień wyżej wskazanych Dyrektyw uzależnione jest od tego, czy przesłuchanie w innych warunkach mogłoby wywrzeć negatywny wpływ na dziecko.

Niewątpliwie uczestnictwo w procesie karnym wpływa negatywnie na psychikę dziecka, zwłaszcza w sytuacji, gdy wkracza się w intymną, a jednocześnie wykorzystaną przez sprawcę, sferę jego życia. Dlatego też zasadą jest, iż przesłuchanie, o którym mowa w art. 185a k.p.k. powinno być przeprowadzane tylko raz w toku całego postępowania - przygotowawczego i sądowego - na posiedzeniu sądowym i w odpowiednich warunkach, co ma na celu ograniczyć ujemne przeżycia pokrzywdzonego związane z popełnieniem przeciwko niemu przestępstwa i pomóc mu zapomnieć o traumatycznym zdarzeniu. Przesłanki podejmowania decyzji o ponownym przesłuchaniu pokrzywdzonego nie zostały określone precyzyjnie. Jednak przyjmuje się, że odstępstwo od powyższej zasady występuje, w dwóch wypadkach. Po pierwsze, jeżeli wyjdą na jaw istotne okoliczności, których wyjaśnienie wymaga ponownego przesłuchania pokrzywdzonego. Po drugie wtedy, gdy zażąda tego oskarżony, który nie miał obrońcy w czasie pierwszego przesłuchania pokrzywdzonego. W tej ostatniej sytuacji nie ma znaczenia, jaki jest powód tego wniosku, ani też czy oskarżony w ogóle go podał. Wystarczający jest sam fakt zgłoszenia żądania przez oskarżonego lub jego obrońcę, by sąd był zobowiązany do ponownego przesłuchania pokrzywdzonego. ${ }^{9}$ Tak więc w przypadku, gdy oskarżony, który nie miał obrońcy w trakcie pierwszego przesłuchania dziecka, złoży żądanie powtórnego przeprowadzenia czynności przesłuchania, wówczas jest ono obowiązkowe. Podobne stanowisko wyraził Sąd Najwyższy w postanowieniu 7 sędziów z dnia 24 listopada 2010 r., w którym stwierdził, że „,W art. 185a k.p.k. ustawodawca jednoznacznie określił zarówno zasady ochrony świadka pokrzywdzonego przestępstwami wymienionymi w tym przepisie, który w chwili przesłuchania nie ukończył 15 lat - przed powtórną wiktymizacją, jak i jej granice, uwzględniając przy tym obowiązek dotarcia do prawdy oraz konieczność zapewnienia podstawowych uprawnień do realizowania obrony przez oskarżonego. Oskarżonemu stworzono możliwość domagania się ponownego przesłuchania pokrzywdzonego i to bez dodatkowych warunków - o ile nie miał obrońcy w czasie, gdy przeprowadzano pierwsze przesłuchanie takiego pokrzywdzonego." ${ }^{10} \mathrm{Z}$ uwagi na konieczność ponownego przesłuchania dziecka w związku

9 Postanowienie SN z dnia 15 marca 2012 r., III KK 244/11, LEX Nr 1157561; Postanowienie SN 7 sędziów z dnia 24 listopada 2010 r., I KZP 21/10, OSNKW 2010, Nr 11, poz. 95.

10 Postanowienie SN 7 sędziów z dnia 24 listopada 2010 r., I KZP 21/10, OSNKW 2010, Nr 11, poz. 95. 
z żądaniem oskarżonego, który nie miał obrońcy w trakcie czynności przesłuchania, ustawodawca $\mathrm{w}$ art. 185a $\S 2$ k.p.k. wprowadził obowiązek przyznawania oskarżonemu obrońcy z urzędu w sytuacji, gdy sąd podejmie decyzję o przesłuchaniu dziecka w charakterze świadka, a oskarżony nie posiada obrońcy z wyboru. Niewątpliwie stanowi to wyraz ochrony interesów małoletniego pokrzywdzonego czy też małoletniego świadka przestępstwa, a jednocześnie nie ogranicza w sposób nadmierny i nieusprawiedliwiony praw oskarżonego. W związku z tym wprowadzona zmiana gwarantuje oskarżonemu prawo do rzetelnego procesu wynikającego z art. 6 ust. 3 lit d Konwencji o ochronie praw człowieka i podstawowych wolności. ${ }^{11}$

Nie bez znaczenia dla zapewnienia prawidłowego przeprowadzenia czynności przesłuchania dziecka pozostaje fakt, że na podstawie art. 185a $\S 2$ k.p.k. organem uprawnionym do przesłuchania jest sąd, który czyni to zarówno $\mathrm{w}$ toku postępowania przygotowawczego, jak i jurysdykcyjnego. Organ ścigania powinien zatem wystąpić do sądu z wnioskiem o przesłuchanie małoletniego pokrzywdzonego. Celem ochrony dziecka przed wtórną wiktymizacją przesłuchanie małoletniego pokrzywdzonego nie powinno następować już w pierwszej fazie postępowania przygotowawczego in rem (prowadzonego w sprawie), zwłaszcza od razu po przyjęciu zawiadomienia o popełnieniu czynu zabronionego. Organ ścigania, tj. policja lub prokurator, powinien wówczas przesłuchać zawiadamiającego dorosłego i rozważyć możliwość przeprowadzenia innych dowodów w postaci badań lekarskich małoletniego pokrzywdzonego, oględzin miejsca zdarzenia, czy też przesłuchania innych świadków. Dopiero dysponując takim materiałem powinien wystąpić do sądu o przesłuchanie małoletniego. Takie postępowanie właściwych organów z jednej strony ma na celu zapewnić, że małoletni pokrzywdzony będzie przesłuchiwany tylko raz, zaś z drugiej, aby przesłuchanie pokrzywdzonego dziecka było przeprowadzane, jeżeli jego zeznania mogą mieć istotne znaczenie dla rozstrzygnięcia sprawy. Mając na uwadze ratio legis art. 185a k.p.k. należy zatem postulować, aby przesłuchanie pokrzywdzonego dziecka następowało dopiero po przedstawieniu zarzutu popełnienia przestępstwa, zwłaszcza że do postawienia takiego zarzutu wystarcza istnienie uzasadnionego podejrzenia popełnienia przestępstwa, co może nastąpić na podstawie chociażby zeznań świadków ze słuchu, tj. rodziców, którym dziecko opowiedziało przebieg zdarzenia. ${ }^{12}$ Podobne stanowisko przedstawił Sąd Najwyższy w wyroku z dnia 24 listopada 2009 r., w którym stwierdził, że ,W sprawach, w których pokrzywdzeni przestępstwami określonymi w rozdziałach XXV i XXVI Kodeksu karnego nie ukończyli w chwili czynu 15 lat, należy dążyć do tego, aby podczas pierwszego przesłuchania pokrzywdzonego, podejrzany miał już obrońcę. Do przesłuchania w trybie art. 185 a k.p.k. winno więc dochodzić już po przedstawieniu za-

11 Konwencja o ochronie praw człowieka i podstawowych wolności z dnia 4 listopada 1950 r. (Dz.U. z 1950 r. Nr 61 , poz. 284, s. 1254 i n.).

12 K. Eichstaedt, Glosa aprobująca do uchwały SN z dnia 30.11.2004 r., I KZP 25/04, „Przegląd Sądowy” 2006, nr 2, s. 151. 
rzutu popełnienia przestępstwa, czyli w fazie postępowania przygotowawczego in personam, a nie we wstępnej fazie tego postępowania in rem. Wówczas istnieje bowiem możliwość wyznaczenia podejrzanemu obrońcy z urzędu, jeżeli nie posiada obrońcy z wyboru. W takich sytuacjach, w większości wypadków, będzie można poprzestać na jednorazowym przesłuchaniu małoletniego pokrzywdzonego, a prawo oskarżonego do obrony nie zostanie naruszone." ${ }^{13}$ Nowelizacja art. 185a k.p.k. stanowi także wyraz wdrożenia do wewnętrznego porządku prawnego postanowień obowiązujących Dyrektyw i przykładowo wskazania wymaga, że w myśl art. 20 Dyrektywy Parlamentu Europejskiego i Rady z dnia 25 października 2012 r. ustanawiającej normy minimalne w zakresie praw, wsparcia i ochrony ofiar przestępstw oraz art. 20 ust. 3 lit. e Dyrektywy Parlamentu Europejskiego i Rady z dnia 13 grudnia 2011 r. w sprawie zwalczania niegodziwego traktowania w celach seksualnych i wykorzystywania seksualnego dzieci oraz pornografii dziecięcej, należy minimalizować liczbę przesłuchań dziecka i umożliwić ponowne przesłuchanie jedynie, gdy jest to konieczne i niezbędne dla celów postępowania karnego.

Wyrazem dostosowania przepisów polskiego postępowania karnego do standardów europejskich jest wprowadzenie do art. 185a k.p.k. obligatoryjnego udziału w przesłuchaniu dziecka biegłego psychologa. Wpływa on pozytywnie na treść przekazywanych zeznań przez dziecko i pozwala na ustalenie psychologicznych czynników wiarygodności ich zeznań jako świadków.

Zgodnie z treścią art. 185a $§ 2$ k.p.k. w przesłuchaniu ma prawo wziąć udział także prokurator, obrońca, pełnomocnik pokrzywdzonego oraz może być obecna osoba wymieniona w art. $51 \S 2$ k.p.k. lub osoba pełnoletnia wskazana przez pokrzywdzonego, jeżeli nie ogranicza to swobody wypowiedzi przesłuchiwanego. Organ procesowy jest zatem obowiązany do zawiadomienia rodziców małoletniego o planowanym przesłuchaniu i dopuszczenia do udziału w nim. Jednakże w sytuacji, gdy mimo wszelkiej sposobności zawiadomienie nie nastąpi i dziecko zostanie przesłuchane pod nieobecność przedstawiciela ustawowego lub opiekuna faktycznego, to takie naruszenie procedury będzie oceniane wyłącznie w kategorii względnej przyczyny odwoławczej. ${ }^{14}$

Udział rodzica lub opiekuna w przesłuchaniu może być wskazany ze względu na zapewnienie w ten sposób bezpieczeństwa „małemu świadkowi”, zwłaszcza gdy jest on w wieku przedszkolnym. Ponadto obecność rodzica podczas przesłuchania będzie stanowiła dla dziecka oparcie, w nowej stresującej dla niego sytuacji, jaką jest składanie zeznań. W postępowaniu przygotowawczym, ze względu na wyłączenie jawności, udział opiekuna spełnia także funkcję gwarancyjną prawidłowo przeprowadzonej czynności oraz kontroli przestrzegania praw dziecka. ${ }^{15}$ Oczywiście udział osoby bliskiej będzie wykluczony w sytuacji, gdy jej obecność ograniczy swobodę

Wyrok SN z dnia 24 listopada 2009 r., III KK 176/09, LEX Nr 553885.

B. Łopalewski, Przesłuchanie małoletniego świadka w procesie karnym, „Jurysta” 2006, nr 12, s. 7.

B. Hołyst, Psychologia kryminalistyczna, Warszawa 2004, s. 964. 
wypowiedzi przesłuchiwanego. Ponadto obecność rodzica jest niewskazana, jeżeli dziecko sugeruje, że nie chce, aby uczestniczył on w przesłuchaniu, gdyż będzie na niego działać krępująco.

Umożliwienie pokrzywdzonemu dziecku, aby w trakcie przesłuchania towarzyszył mu przedstawiciel prawny lub wybrana przez dziecko inna osoba dorosła, o ile nie podjęto $\mathrm{w}$ tym zakresie decyzji odmownej wynika także wprost $\mathrm{z}$ treści wskazanych Dyrektyw zmierzających do ochrony tej szczególnej kategorii świadków. Tym samym stanowi to potwierdzenie, że procedura przesłuchania dziecka w polskim procesie karnym jest dostosowana do przyjętych standardów europejskich, które powinny być wdrażane do systemów prawnych państw członkowskich.

Wyrazem przyjęcia przez Polskę unormowań wynikających z dyrektyw zmierzających do lepszego zabezpieczenia interesów dziecka i przyznania mu szeregu praw w postępowaniu karnym jest wprowadzenie do kodeksu postępowania karnego art. 185d k.p.k., który stanowi, że przesłuchanie w trybie art. 185a-185c przeprowadza się w odpowiednio przystosowanych pomieszczeniach w siedzibie sądu lub poza jego siedzibą. Zasadniczym celem powstania takiego szczególnego pomieszczenia - Przyjaznego Pokoju Przesłuchań Dzieci jest ograniczenie do minimum liczby przesłuchań dzieci, aby nie narażać ich na ponowne przeżywanie traumatycznych wydarzeń. Ponadto celem stworzenia tych pokoi jest także minimalizowanie stresu dziecka związanego z przeżywaniem nowego doświadczenia, jakim jest niewątpliwie przesłuchanie oraz zgromadzenie wiarygodnego materiału dowodowego. ${ }^{16} \mathrm{~W}$ Przyjaznym Pokoju Przesłuchań Dzieci dziecko pokrzywdzone przestępstwem lub będące jego świadkiem w przyjaznej atmosferze może przekazać wartościowe informacje o przebiegu zdarzenia przestępczego, które następnie mogą być podstawą do wydania wyroku skazującego. Jednocześnie wyposażenie Przyjaznego Pokoju Przesłuchań Dzieci w urządzenia rejestrujące obraz i dźwięk umożliwiają wypełnienie postulatu ustawodawcy jednokrotnego przesłuchania dziecka w toku całego postępowania. Jednakże, aby przesłuchanie odbyło się w sposób prawidłowy i nie spowodowało ponownego pokrzywdzenia ofiary, należy zapewnić tej szczególnej kategorii ofiar, aby przesłuchanie prowadzone było przez odpowiednio przeszkoloną do tego osobę, która posiada umiejętność i wiedzę w zakresie stosowania szczególnych środków, a zwłaszcza właściwych metod przesłuchania, które powinny uwzględniać wyjątkową sytuację ofiary.

Nie można pominąć, że osiągnięcie celu przyświecającego wprowadzonym do kodeksu postępowania karnego regulacjom art. 185a i 185b, zawierającym postanowienia odpowiadające standardom europejskim w zakresie przesłuchania dziecka, jest możliwie tylko wówczas, gdy przesłuchanie dziecka zostanie każdorazowo po-

16 Standardy miejsca przesłuchania dzieci, które powinien spełniać Przyjazny Pokój Przesłuchań Dzieci, zostały one sformułowane w 2007 r. przez Fundację Dzieci Niczyje i Ministerstwo Sprawiedliwości we współpracy z Koalicją na rzecz Przyjaznego Przesłuchiwania Dzieci, www.ms.gov.pl/pl/dzialalnosc/ przeciwdzialanie-przemocy-wobec-dzieci/przyjazne-przesluchanie-dziecka 
przedzone stosownymi przygotowaniami zarówno przesłuchującego, jak i przesłuchiwanego. Przed rozpoczęciem przesłuchania przesłuchujący powinien zapoznać się z zebranym materiałem, np. protokołami przesłuchań innych świadków, oględzin, czy też opiniami biegłych. Przejrzenie akt umożliwia właściwe przygotowanie pytań zadawanych później świadkowi, jak również w miarę konieczności przeprowadzenia okazania, gdy istnieje prawdopodobieństwo, że świadek widział sprawcę czynu zabronionego przez prawo. W ten oto sposób zapobiega się powtarzaniu czynności i tzw. dosłuchiwaniu świadka oraz sprzyja ekonomice postępowania w danej sprawie.

Duży wpływ na wartość uzyskanych od dziecka zeznań oprócz odpowiedniego przygotowania się, czasu i miejsca, w jakim odbywa się przesłuchanie ma również sama czynność przesłuchania, której prawidłowy przebieg jest związany z określonym zachowaniem się przesłuchującego, zadawaniem odpowiednio sformułowanych pytań oraz właściwym jej zaprotokołowaniem lub utrwaleniem za pomocą dźwięku lub obrazu. W związku z tym pozytywnie należy ocenić wprowadzenie do kodeksu postępowania karnego bezwzględnego obowiązku rejestrowania przebiegu przesłuchania pokrzywdzonego, o którym mowa w art. 185a k.p.k. oraz świadka, o którym mowa w art. 185b k.p.k. za pomocą urządzenia rejestrującego obraz i dźwięk (art. 147 § 2a k.p.k.). ${ }^{17}$ Umożliwia to przeprowadzenie czynności przesłuchania bez konieczności bezpośredniego kontaktu z oskarżonym. Konsekwencją wprowadzenia przedmiotowej zmiany jest obowiązek odtworzenia na rozprawie sporządzonego zapisu obrazu i dźwięku przesłuchania dziecka. Pozwala to na wierne wypełnianie postulatów ustawodawcy w zakresie jednorazowego przeprowadzenia czynności przesłuchania w toku całego postępowania i tym samym ochrony dziecka przed koniecznością ponownego opowiadania na rozprawie o przebiegu traumatycznego zdarzenia. Rejestracja przesłuchania i możliwość odtworzenia jego przebiegu na rozprawie w praktyce zniweluje składanie przez oskarżonych wniosków o ponowne przesłuchanie świadka oraz zabezpieczy realizację zasady bezpośredniości i prawa do obrony. Założenie takie jest także odpowiednikiem postanowień wskazanych Dyrektyw, które stanowią, że przesłuchanie dziecka powinno być rejestrowane techniką wideo i stanowi dowód w postępowaniu karnym, bez konieczności powtarzania czynności.

Reasumując, wejście w życie dyrektyw uchwalonych przez Parlament Europejski i Radę spowodowało konieczność wprowadzenia zmian w dotychczasowych przepisach wewnętrznych dotyczących przesłuchania dziecka w postępowaniu karnym we wszystkich państwach członkowskich, w tym w Polsce, celem dostosowania obowiązującego porządku prawnego do postanowień dyrektyw. W Polsce wyrazem wdrożenia standardów europejskich w zakresie przesłuchania dziecka jest

17 Art. 147 § 2a k.p.k. dodany przez art. 2 pkt 2 lit. b) ustawy z dnia 13 czerwca 2013 r. o zmianie ustawy - Kodeks karny oraz ustawy - Kodeks postępowania karnego (Dz.U. z 2013 r. Nr 849) zmieniającej nin. ustawę z dniem 27 stycznia 2014 r. 
wprowadzenie, a następnie znowelizowanie dotychczasowych regulacji, a mianowicie art. 185a i 185b k.p.k. W ocenie Autorki jest to działanie korzystne, gdyż nie tylko umożliwia zapewnienie dzieciom lepszej ochrony w trakcie czynności przesłuchania, ale także wpływa na uzyskanie wartościowego dowodu w sprawie i zapobieganie narażaniu ich na ponowne pokrzywdzenie ze strony organów ścigania i przedstawicieli wymiaru sprawiedliwości. Przede wszystkim pozytywnie należy ocenić proponowane $\mathrm{w}$ dyrektywach, a znajdujące odzwierciedlenie $\mathrm{w}$ przepisach polskiego kodeksu postępowania karnego, postanowienia odnoszące się do minimalizowania liczby przesłuchań dzieci, przyznanie im prawa do unikania kontaktu ze sprawcą, przeprowadzania przesłuchania $\mathrm{w}$ specjalnie przystosowanych pomieszczeniach, utrwalenia audiowizualnego przesłuchania celem wykorzystania go jako dowodu w postępowaniu przed sądem, jak również zapewnienia, aby w przesłuchaniu dziecka brał udział przedstawiciel prawny lub inna wybrana przez dziecko osoba dorosła. 
THE HEARING OF A CHILD IN POLISH CRIMINAL PROCEEDINGS IN THE LIGHT OF EUROPEAN STANDARDS

The increase in awareness of the issue of child abuse is associated with increasing attentiveness to the worldwide protection of children's rights in criminal proceedings, strengthening the position of a child that is the victim of a crime during criminal proceedings, protection of the child's legitimate interests and prevention of secondary victimization by law enforcement agencies and the administration of justice. It is evidenced by international requirements and recommendations which the legislation of each country should meet. With reference to those actions, in recent years a wide-ranging policy has been adopted by European Union member states, including Poland, aimed at providing comprehensive protection to a child in the course of interrogation during criminal proceedings.

European standards concerning the interrogation of children in criminal proceedings and safeguard of their legitimate interests are reflected in Polish criminal procedure. Article 185 of the code of criminal procedure, serves as an expression of the concerns attached to children who are victims of a crime and the methods that are to be adopted when questioning them. Similarly, article $185 \mathrm{~b}$ of the code, addresses the methods to be adopted when questioning children who are witness to a crime.

Keywords: child, victim, witness of a crime, criminal proceedings, hearing 